\title{
Antarctic ice-rafted detritus (IRD) in the South Atlantic: Indicators of iceshelf dynamics or ocean surface conditions?
}

\author{
Simon H. H. Nielsen ${ }^{1}$ and D. A. Hodell ${ }^{1,2}$
}

${ }^{1}$ Department of Geological Sciences, University of Florida, Gainesville, Florida 32611, USA (Hodell@ufl.edu), ${ }^{2}$ now at Department of Geological Sciences, Florida State University, 108 Carraway Building, Tallahassee, FL 32306, USA (nielsen@gl.fsu.edu).

Abstract Ocean sediment core TN057-13PC4/ODP1094, from the Atlantic sector of the Southern Ocean, contains elevated lithogenic material in sections representing the last glacial period compared to the Holocene. This ice-rafted detritus is mainly comprised of volcanic glass and ash, but has a significant input of what was previously interpreted as quartz during peak intervals (Kanfoush et al., 2000, 2002). Our analysis of these clear mineral grains indicates that most are plagioclase, and that South Sandwich Islands is the predominant source, similar to that inferred for the volcanic glass (Nielsen et al., in review). In addition, quartz and feldspar with possible Antarctic origin occur in conjunction with postulated episodes of Antarctic deglaciation. We conclude that while sea ice was the dominant ice rafting agent in the Polar Frontal Zone of the South Atlantic during the last glacial period, the Holocene IRD variability may reflect Antarctic ice sheet dynamics.

Citation: Nielsen, S.H.H. and D.A. Hodell (2007): Antarctic ice-rafted detritus in the South Atlantic: Indicators of iceshelf dynamics or ocean surface conditions?, in Antarctica: A Keystone in a Changing World - Online Proceedings of the 10th ISAES, edited by A.K. Cooper and C.R. Raymond et al., USGS Open-File Report 2007-1047, Short Research Paper 020, 5 p.; doi:10.3133/of2007-1047.srp020.

\section{Introduction}

Kanfoush et al. (2000) studied ice-rafted detritus (IRD) in high-sedimentation-rate cores along a north-south transect in the eastern Atlantic sector of the Southern Ocean (Fig. 1; Shipboard Scientific Party, 1999). They identified six to seven discrete episodes of IRD deposition, SA-IRD events, between 12 and 60 ka (Fig. 2), and showed these to be correlative along a north-south transect at roughly $4^{\circ} \mathrm{E}$ from $\sim 41^{\circ} \mathrm{S}$ in the Cape Basin to south of the modern Antarctic Polar Front at $\sim 53^{\circ} \mathrm{S}$ (Kanfoush et al., 2000). In addition, Hodell et al. (2001) observed a similar event near $5 \mathrm{ka}$, here labeled SAH1 (Fig. 2). Kanfoush et al. (2002) also reported a significant amount of quartz in glacial-aged sediment, and interpreted it to be sourced from Antarctica. They proposed that the episodic deposition of discrete layers of Antarctic-derived IRD may indicate instability of Antarctic ice sheets leading to increased production of icebergs. However, such direct correlation between open ocean IRD deposition and Antarctic glacial dynamics has been questioned (Clark and Pisias, 2001).

Nielsen et al. (in review) established the provenance of the dominant volcanic glass and ash in the glacial South Atlantic IRD events (SA-IRD events), and found this component ( $\sim 90 \%$ of the total lithics) to be almost exclusively derived from South Sandwich Islands (SSI) based on geochemical evidence. Most of what remains was previously interpreted to be quartz (Kanfoush et al., 2000 and 2002), but is a mix of clear minerals, mainly plagioclase and olivine phenocrysts from SSI, as well as alkalifeldspar and quartz with unkown sources. Nielsen et al. (in review) suggest that the two latter mineral groups may be derived from Antarctica, but that their contributions are as low as 1-7\% of the total IRD.

Here we further investigate the mineralogical and elemental data of the TN057-13PC4/ODP1094 clear mineral grains to identify other sources of IRD in South
Atlantic sediments during the last glacial period, and establish whether Antarctic glacial history is reflected in the coarse lithogenic fraction of South Atlantic deep-sea sediment.

\section{Site Locations}

We studied sediment in cores recovered from two sites near the Antarctic Polar Front on the Ocean Drilling Program (ODP) Leg 177 transect in the eastern Atlantic sector of the Southern Ocean (Fig. 1). This region is strongly influenced by the Antarctic Polar Front (APF), a maximum in the steady eastward flow of the Antarctic Circumpolar Current (ACC) and westerly winds (Orsi et al., 1995; Moore et al., 1999). Today, the winter sea-ice edge is located at $\sim 55^{\circ} \mathrm{S}$ in the eastern Atlantic Southern Ocean (Schweitzer, 1995), and may have been as far north as $48^{\circ} \mathrm{S}$ in the Atlantic Southern Ocean during the last glacial period (Crosta et al., 1998).

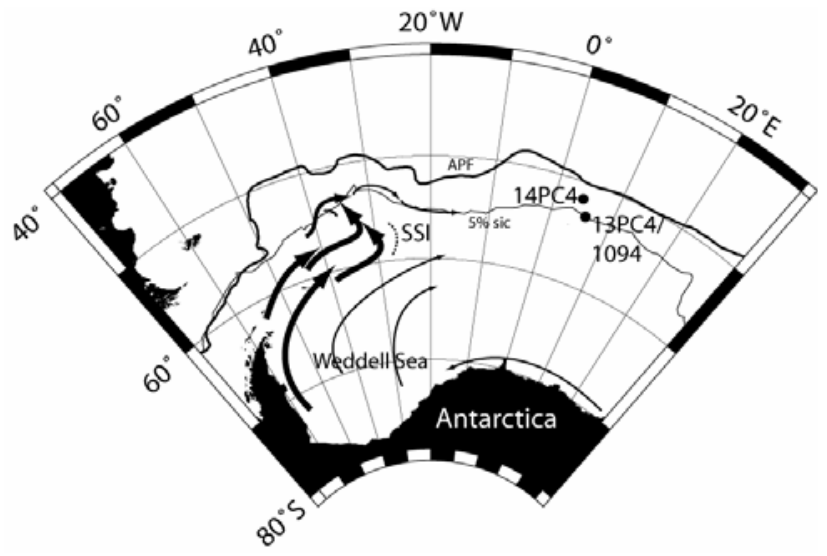

Figure 1. Field area, with the position of piston core TN057-13PC4 (13PC4) in relation to ODP Site 1094 and TN057-14PC4 (14PC4). Position of the Antarctic Polar Front (APF) from Moore et al. (1999). Maximum northward extent of $>5 \%$ sea ice concentration ( $5 \%$ sic) from Schweitzer (1995). 


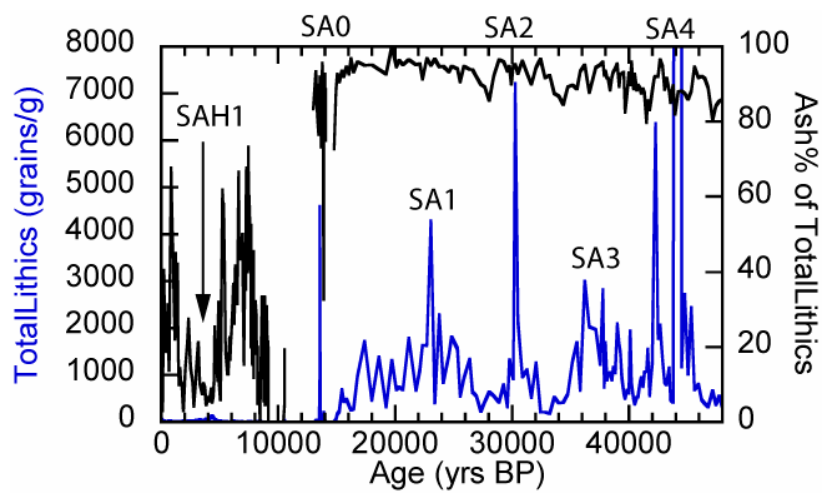

Figure 2. The six SA-IRD events investigated here, as represented in number of grains per gram of dried sample (blue line). In order of appearance: SA4 (48-42 ka), SA3 (38-35 ka), SA2 (31-30 ka), SA1 (28-22 ka), SA0 (13.8 $\mathrm{ka})$ and SAH1 (4.2 ka). The black line is the relative abundance of volcanic ash and glass grains in the total coarse lithics fraction. The timescale is updated from Kanfoush et al. (2000) and Hodell et al. (2001) by Nielsen et al. (unpublished data).

Cores TN057-13PC4 and TN057-14PC4 are both 14meter-long jumbo piston cores obtained in 1996 on cruise TN057 aboard the R/V Thomas Thompson. Ocean Drilling Program Site 1094 was drilled at the same location as TN057-13, about $2^{\circ}$ north of the modern seaice edge (Shipboard Scientific Party, 1999). TN057-14 is located about $1^{\circ}$ further north of TN057-13 (Fig. 1).

\section{Methods}

We analyzed IRD from the six youngest SA-IRD events (Fig. 2): SA4 to SA1 from the last glacial period, SA0 from the last deglaciation (Kanfoush et al., 2000), and SAH1 in the Holocene (called the Neoglacial in Hodell et al. (2001)). Clear minerals were picked, but not sorted, and mounted on glass slides for microprobe analysis. The data acquisition method is presented in full in Nielsen et al. (in review).

The resulting major elemental data was used to separate mineral types, and quartz grain data was further subjected to Principal Components Analysis (PCA). To reduce the influence of the dominant $\mathrm{SiO} 2$ and enhance the impact of low abundance oxides, the quartz data were treated with square-root transformation.

\section{Results}

Based on microprobe analysis, three types of minerals are present in the clear mineral assemblages of TN05713PC4 and ODP1094: (on average) 71\% feldspar, 25\% quartz, and $3 \%$ olivine (Table 1).

Most feldspar grains in TN057-13PC4 and ODP 1094 are small, colorless, and transparent with sub- to euhedral crystal shape. Larger crystals are more irregular, with a yellow or white hue, and sometimes milky in appearance. The feldspar groups in four distinct clusters in a ternary diagram (Fig. 3). The dominant group (59\%, Table 1) consists mainly of plagioclase, especially high-Ca anorthite and bytownite (An95-70), here labeled high-Ca plagioclase. The next most abundant group includes the mid-range plagioclases: andesine-labradorite (An55-40). Only a few grains are albitic (An30-0), and grouped as high-Na plagioclase. Alkali feldspars are mainly orthoclase, clustering around Or45-60 and in a highpotassium group (Or80-98), both included in the orthoclase group.

Quartz grains are clear to yellow or smoky, and subrounded to rounded. Principle components analysis of quartz grains indicates that the chemical variability is controlled mainly by $\mathrm{Fe}, \mathrm{K}, \mathrm{Mn}$, and to a lesser extent $\mathrm{Ca}$ and $\mathrm{Al}$ (Fig. 4; Table 1). Four groups are recognized based on this variability (Table 1): the FeK quartz group, a low $\mathrm{FeO}$ group, Clean Quartz, and $\mathrm{MnO}$ quartz (Fig. 4; Table 1). The olivine is forsteritic (Fo70-85).

\section{Discussion}

\section{Sources of clear minerals}

The basic mineralogy of the clear minerals can be used for a first estimate of origin. Quartz is most likely sedimentary or metamorphic in origin, suggesting continental sources, whereas feldspars can have magmatic origins.

Major elemental analysis of single clear mineral grains further narrows the range of possible sources; because of the chemical purity of quartz, any geochemical variability is likely controlled by inclusions. Quartz with relatively high amounts of iron and potassium may be from continental sandstones and arkoses, whereas pure quartz and quartz with low amounts of manganese or iron may be hydrothermal and possibly deep marine in origin.

Table 1. Major oxide chemistry of each grain type found through the microprobe study.

\begin{tabular}{|c|c|c|c|c|c|c|c|c|c|c|c|}
\hline Groups & $\begin{array}{c}\text { No. } \\
\text { Grains }\end{array}$ & $\begin{array}{l}\% \text { of clear } \\
\text { minerals }\end{array}$ & $\mathrm{SiO}_{2}$ & $\mathrm{TiO}_{2}$ & $\mathrm{~A}_{12} \mathrm{O}_{3}$ & $\mathrm{FeO} *$ & MnO & MgO & $\mathrm{CaO}$ & $\mathrm{Na}_{2} \mathrm{O}$ & $\mathrm{K}_{2} \mathrm{O}$ \\
\hline Clean Qz & 34 & 10 & 99.5 & 0.0 & 0.0 & 0.0 & 0.0 & 0.0 & 0.0 & 0.0 & 0.0 \\
\hline Low Fe Qz & 11 & 3 & 98.5 & 0.0 & 0.0 & 0.1 & 0.0 & 0.0 & 0.0 & 0.0 & 0.0 \\
\hline FeK Qz & 27 & 8 & 99.5 & 0.0 & 0.0 & 0.3 & 0.0 & 0.0 & 0.0 & 0.0 & 0.1 \\
\hline Mn Qz & 10 & 3 & 98.5 & 0.0 & 0.0 & 0.0 & 0.2 & 0.0 & 0.0 & 0.0 & 0.0 \\
\hline Hi Ca Plag & 191 & 59 & 46.8 & 0.0 & 34.1 & 0.6 & 0.1 & 0.0 & 17.1 & 1.4 & 0.0 \\
\hline Mid Plag & 23 & 7 & 57.0 & 0.0 & 27.3 & 0.4 & 0.1 & 0.0 & 9.1 & 5.9 & 0.2 \\
\hline K spar & 14 & 4 & 65.7 & 0.0 & 19.2 & 0.2 & 0.0 & 0.0 & 0.2 & 2.3 & 13.7 \\
\hline Hi Na Plag & 4 & 1 & 66.3 & 0.0 & 20.7 & 0.3 & 0.0 & 0.0 & 0.8 & 11.6 & 0.2 \\
\hline Olivines & 11 & 3 & 39.8 & 0.0 & 0.0 & 17.9 & 0.4 & 42.0 & 0.1 & 0.0 & 0.0 \\
\hline
\end{tabular}




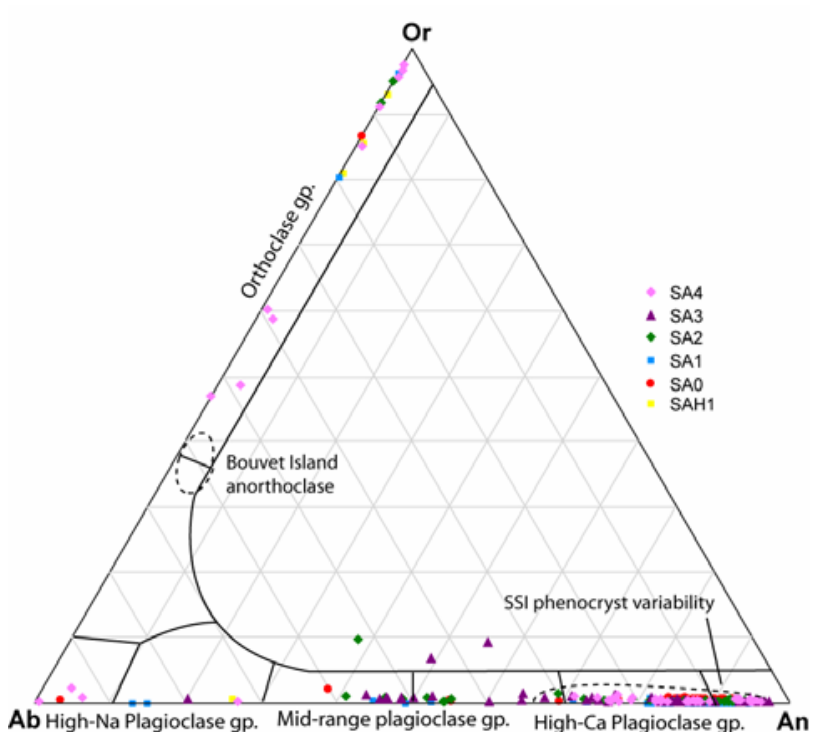

Figure 3. Ternary diagram with encountered feldspar composition plotted against the end members. Four groups can be recognized: High-Ca, Mid-range and HighNa plagioclase groups, and the orthoclase group. South Sandwich Island (SSI) phenocryst variability from Pearce et al. (1995). Bouvet Island anorthoclase phenocryst data from Verwoerd (1990).

There is no previous study of Antarctic quartz provenance, so derivations are based on speculation and co-occurrence with feldspar groups.

Feldspar composition can be magmatic and controlled by melt composition and temperature. Sodic and potassic feldspars are characteristic of felsic rocks and their derived sediments, whereas the more calcic plagioclases derive from basaltic and andesitic sources. The dominant plagioclase group, high-Ca plagioclase, has compositions within the range of Ca-plagioclase phenocrysts in South Sandwich Islands (Fig. 3; Pearce et al., 1995). This plagioclase ranges from $48 \%$ of the total clear mineral assemblage during SA4 (E and $\mathrm{F}$ ashes) to almost 85\% during SA0 (Fig. 5). During the Holocene SAH1 event no SSI-related clear minerals are present. Olivine in our samples is similar in composition to the range observed for olivine phenocrysts in the SSI (Fo60-80).

The SSI-derived clear mineral component seems to reflect the abundance of volcanic ash and glass, which increases from $85 \%$ prior to SA4 to $95 \%$ during SA0, then drops to less than $10 \%$ during SAH1 (Fig. 2).

If the Ca-rich plagioclase and olivine are sourced from SSI, the more sodic feldspars (Na-plagioclase and midrange plagioclase groups) may be derived from the West Antarctic alkali basalt and trachytic provinces. These feldspar groups show a maximum during SA3, followed by diminishing relative abundances until SA0. During the Holocene SAH1 event, these feldspar abundances increase again (Fig. 5).

Quartz comprises 7-22\% of the clear mineral fraction in the glacial SA-IRD layers investigated here, the oldest layers having the most quartz (Fig. 5). During SAH1, quartz makes up $86 \%$ of the clear mineral assemblage (Fig. 5). The clean quartz group (other elements rarely $>0.07 \%$ ) co-occur with $\mathrm{FeK}$ quartz during SA4, in a sample with low amounts of plagioclase and relatively high orthoclase contents (Fig. 5). The outlet for this IRD could be the Filchner Ice Shelf, which drains the East Antarctic Ice Sheet (EAIS). Abundant, quartz-rich sediment is present in the Crary Trough near the front of the Filchner Ice Shelf (Andrews, 1984). This is in agreement with investigations from the Antarctic coast suggesting that the EAIS retreated from the shelf regions before 40 ka (Maemoku et al., 1997; Domack et al., 1991), leading to a reduced EAIS component in SA-IRD after $40 \mathrm{ka}$. A mid-Holocene Antarctic deglacial event has also been suggested (Berkman et al., 1998).

The West Antarctic Ice Sheet (WAIS) is a potential source for pulses of iceberg rafting to the South Atlantic through its inherent close connection to climate and sea level (Mercer, 1978; Domack et al., 2005). Sediment derived from the WAIS is transported northwards along the Antarctic Peninsula by the Weddell Gyre (Fig. 1; Diekmann and Kuhn, 1999). During SA3-SA0 in TN05713PC4, $\mathrm{MnO}$ and low $\mathrm{FeO}$ quartz groups occur with the mid-range plagioclase group (Fig. 5). The higher content of $\mathrm{Na}$ in these plagioclases suggests an alkaline source, such as West Antarctica and the older parts of the Scotia Arc (LeMasurier and Thomson, 1990), or sediment subducted under the Scotia Arc (Leat et al., 2004). As a consequence, as suggested by the general Antarctic deglaciation between 35-20 ka (Berkman et al., 1998), WAIS-IRD must have entered the South Atlantic during the last glacial period although in very low amounts.

In summary, the clear mineral fraction of the IRD is a mix of SSI and Antarctic material (Fig. 5). Starting with

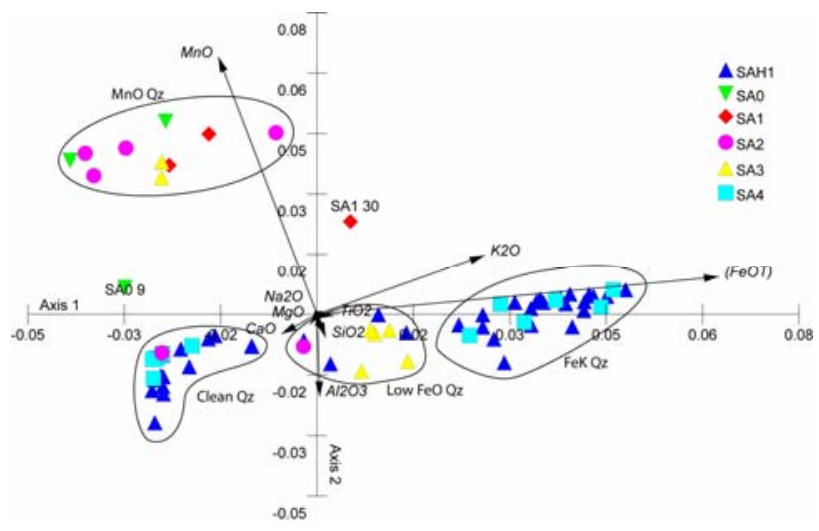

Figure 4. Principal components analysis on the squareroot-transformed quartz major element data. Four groups can be recognized, based mainly on the variability of $\mathrm{MnO}, \mathrm{FeO}(\mathrm{T}), \mathrm{K}_{2} \mathrm{O}$ and $\mathrm{Al}_{2} \mathrm{O}_{3}$ : Clean quartz, Low $\mathrm{FeO}$ quartz, FeK quartz and $\mathrm{MnO}$ quartz. Symbol shape and color refer to the event the grains belong to, which illustrates the dominance of Clean and FeK quartz during SA4 and SAH1. 


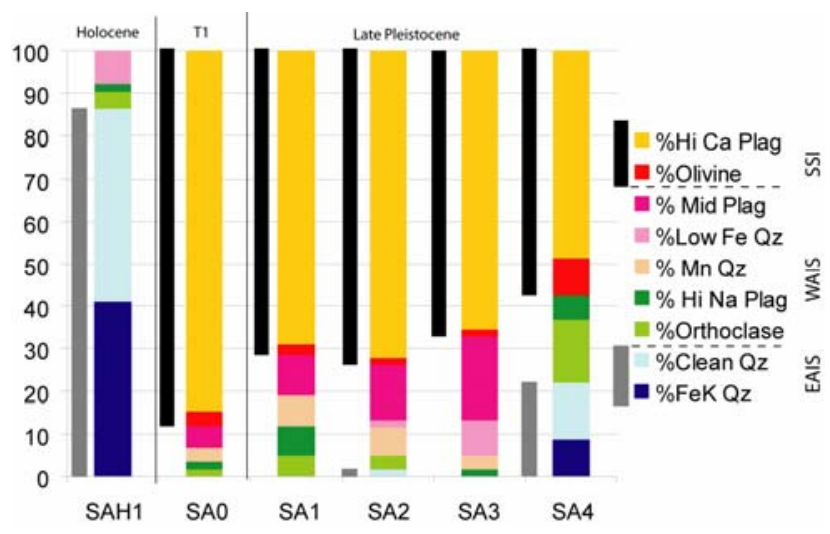

Figure 5. The clear mineral composition of each event as a block diagram, with the mineral groups from Table 1 grouped to represent suggested icesheet sources. Black bars represent total South Sandwich Islands contribution and grey bars the total East Antarctic Ice Sheet contribution. The space between these bars represents the uncertain West Antarctic Ice Sheet contribution.

the oldest samples, the SSI component gradually increases during the progression of the last glacial period at the expense of the Antarctic component; from 57\% during SA4 to $88 \%$ during SA0 (Fig. 5). These fractions can be used to further correct the relative contributions of Antarctica and local South Atlantic volcanic sediment sources presented by Nielsen et al. (in review). If the 'quartz' estimates of Kanfoush et al. (2002) are adjusted by removing the fraction of SSI clear minerals and adding these to the counts of ash grains, then the Antarctic component of the total IRD varies from 7\% during SA4 to less than 1\% during SA3-SA0 (Nielsen et al., in review). The main reason for the decrease in Antarctic IRD after SA4 is the loss of the East Antarctic component from the clear mineral fraction (Fig. 5).

\section{Mode of Transport/Deposition}

Nielsen et al. (in review) suggests that sea-ice rafting appears to be the main source of South Atlantic IRD, since this is largely comprised of volcanic sediment from local sources. It is here shown that the clear mineral group is a mixture of phenocrystic feldspar and olivine from mainly local sources, as well as a minor input of quartz. This has implications for the possible modes of IRD transport and their contributions to the total lithogenic deposition at the TN057-13PC4 site.

The northward extended winter sea-ice edge during the last glacial period made it more likely that sea ice would survive the journey from SSI to our core localities, which for the most part can explain the IRD peaks in TN05714PC4 (Nielsen et al., in review), and therefore also those in nearby TN057-13PC4 (Fig. 2). Figure 2 further shows the relative abundance of volcanic ash in TN057-13PC4. It is apparent that the dominance of this ash during the last glacial period changed little during the SA events, suggesting that the increased clear mineral presence during SA events is related to the ash abundance. Sea ice variability must then also be the main control on glacial clear mineral abundance, and the SA peaks themselves become indications of increased iceberg survivability rather than an indicator of any Antarctic iceshelf dynamics. This is supported by the mineral composition and major element chemistry, which suggests mainly SSI and WAIS sources, with only a minor EAIS contribution during SA4 (Fig. 5).

The ash component of the total lithics dropped to essentially zero after $12 \mathrm{ka}$, and was never more than $70 \%$ during the generally IRD-poor Holocene interval (Fig. 2). The mid-Holocene SAH1 event, the 'Neoglacial' of Hodell et al. (2001), contrasts the glacial IRD events by occurring in an interval of reduced ash abundance (Fig. 2). The mineralogy and geochemistry of this event is dominated by possible East Antarctic IRD (Fig. 5).Given no other evidence, this suggests another mode of deposition, by which increased rafting of EAIS sediment by large tabular icebergs brought IRD to the TN05713PC4/ODP1094 site.

\section{Conclusions}

Two mechanisms seem to control the rafting of Antarctic IRD to the open ocean: increased iceberg survivability during periods of extensive sea ice presence, and increased rafting of icebergs from Antarctica.

Due to the dominance of ash and SSI-sourced clear minerals during the five oldest SA-events, we suggest that sea ice was the dominant glacial ice-rafting agent, transporting volcanic sediments from mainly the SSI to core locations in the PFZ of the eastern South Atlantic. The location of the SSI makes them obvious targets for wind and wave erosion, dispersing volcanic sediment onto local sea ice. Drift of the ice as well as prevailing winds will transport the volcanic sediment eastward, to be deposited when the sediment is blown off the ice or the ice melts. Glacial IRD abundance therefore reflects mainly changing ocean surface conditions, with high amounts of IRD indicating extensive sea ice presence due to increased storminess and/or cooler conditions. A small presence of mainly WAIS-derived IRD during the glacial SA-events suggests increased iceberg survivability during these periods, while neither supporting nor contradicting possible Antarctic glacial dynamics.

The comparatively small Holocene SAH1 event has a dominant EAIS source, and little volcanic material. This suggests an episode of increased rafting of Antarctic icebergs in a time of otherwise reduced sea ice presence.

Acknowledgements TN057-14PC4 samples were acquired from LDEO Core Repository. This work was supported by NSF grant \#0350402. Thanks to Sharon L. Kanfoush for data and discussions, as well as to Denise K. Kulhanek for comments and correcting English. This manuscript was significantly improved by suggestions from Dieter Fütterer, Yusuke Yokoyama and Frank Lamy.

\section{References}

Andrews, B.A. (1984), A Petrological study of Weddell Sea sediments: Implications for provenance and glacial history. Master of Arts Thesis, Rice University, 202pp. 
Berkman, P.A., et al. (1998): Circum-Antarctic environmental shifts during the Late Quaternary reflected by emerged marine deposits, Antarctic Science, 10(3), 345-362.

Clark, P. U., and N.G. Pisias (2000), Interpreting Iceberg Deposits in the Deep Sea, Science, 290, 51-52.

Crosta, X., J.-J. Pichon and L.H. Burckle (1998), Application of modern analog technique to marine Antarctic diatoms: Reconstruction of maximum sea-ice extent at the Last Glacial Maximum, Paleoceanography, 13(3), 284-297.

Diekmann, B., and G. Kuhn (1999), Provenance and dispersal of glacialmarine surface sediments in the Weddell Sea and adjoining areas, Antarctica: ice-rafting versus current transport, Marine Geology, 158, 209-231.

Domack, E.W., A.J.T. Jull, and S. Nakao (1991), Advance of East Antarctic outlet glaciers during the Hypsithermal: Implications for the volume state of the Antarctic Ice Sheet under global warming, Geology, 19, 1059-1062.

Domack, E.W. et al., (2005), Stability of the Larsen B ice shelf on the Antarctic Peninsula during the Holocene epoch, Nature, 436, doi:10.1038/nature03908.

Hodell, D.A., S.L. Kanfoush, A. Shemesh, X. Crosta, C.D. Charles, and T.P. Guilderson (2001), Abrupt Cooling of Surface Waters and Sea Ice Expansion in the South Atlantic Sector of the Southern Ocean at 5000 cal. yr BP, Quaternary Research, 56, 91-198.

Kanfoush, S.L., D.A. Hodell, C.D. Charles, T.P. Guilderson, P.G. Mortyn, and U.S. Ninnemann (2000), Millennial-scale instability of the Antarctic Ice Sheet During the Last Glaciation, Science, 288, 1815-1818.

Kanfoush, S.L., D.A. Hodell, C.D. Charles, T.R. Janecek and F.R. Rack (2002), Comparison of ice-rafted debris and physical properties in ODP Site 1094 (South Atlantic) with the Vostok ice core over the last four climatic cycles, Pal. Pal. Pal. 182, 329-349.

Leat, P.T., J.A. Pearce, P.F. Barker, I.L. Millar, T.L. Barry and R.D. Larter (2004), Magma genesis and mantle flow at a subducting slab edge: the South Sandweich arc-basin system, Earth Planet. Sci. Lett., 227, 17-35.
LeMasurier, W.E. and J.W. Thomson (1990): Volcanoes of the Antarctic Plate and Southern Ocean, Antarctic Research Series, 48, 487 pp., AGU, Washington DC.

Maemoku, H., H. Miura, S. Saigusa, K. Moriwaki (1997), Stratigraphy of the Late Quaternary raised beach deposits in the northern part of Langhovde, Lützow-Holm Bay, East Antarctica, Proc. NIPR. Symp. Antarct. Geosci., 10, 178-186.

Mercer, J.H. (1978), West Antarctic Ice Sheet and CO2 greenhouse effect: a threat of disaster, Nature, 271, 321-325.

Moore, J.K., M.R. Abbott, and J.G. Richman (1999), Location and dynamics of the Antarctic Polar Front from satellite sea surface temperature data, J. Geophys. Res. Ocean, 104, 3059-3073.

Nielsen, S.H.H., D.A. Hodell, G. Kamenov, T. Guilderson, and M. Perfit: Origin and significance of ice rafted detritus in the Atlantic sector of the Southern Ocean. Geo-cubed, in review.

Orsi, A.H., T. Withworth III, W.D. Nowlin, Jr. (1995), On the meridional extent and fronts of the Antarctic Circumpolar Current, Deep-Sea Research I, 42, 641-673.

Pearce, J.A., P.E. Baker, P.K. Harvey and I.W. Luff (1995), Geochemical Evidence for Subduction Fluxes, Mantle Melting and Fractional Crystallization Beneath the South Sandwich Island Arc, Journal of Petrology, 36(4), 1073-1109.

Schweitzer, P.N. (1995), Monthly average polar sea-ice concentration, U.S. Geological Survey Digital Data Series DDS-27, U.S. Geological Survey, Reston, Virginia, 1995.

Shipboard Scientific Party (1999), Site 1094, In Gersonde, R., Hodell, D.A., Blum, P., et al., Proc. ODP, Init. Repts., 177, 1-73 [Online]. Available from World Wide Web: http://www-odp.tamu.edu/ publications/177_IR/VOLUME/CHAPTERS/CHAP_09.PDF. [Cited 2007-06-07].

Verwoerd, W.J. (1990), F.1 Bouvetøya, in Volcanoes of the Antarctic Plate and Southern Oceans, edited by LeMasurier, W.E. and J.W. Thomson, Antarctic Research Series, 48 (1990), 405-410, AGU, Washington DC. 